Document downloaded from:

http://hdl.handle.net/10251/122557

This paper must be cited as:

Doménech Carbó, A.; Domenech Carbo, MT.; Castelló Palacios, A.; Guerola Blay, V.; Pérez Marín, E. (2019). Electrochemical identification of painters/workshops: The case of Valencian Renaissance-Baroque painters (ca. 1550- ca. 1670). Electrochimica Acta. 297:685-695. https://doi.org/10.1016/j.electacta.2018.11.212

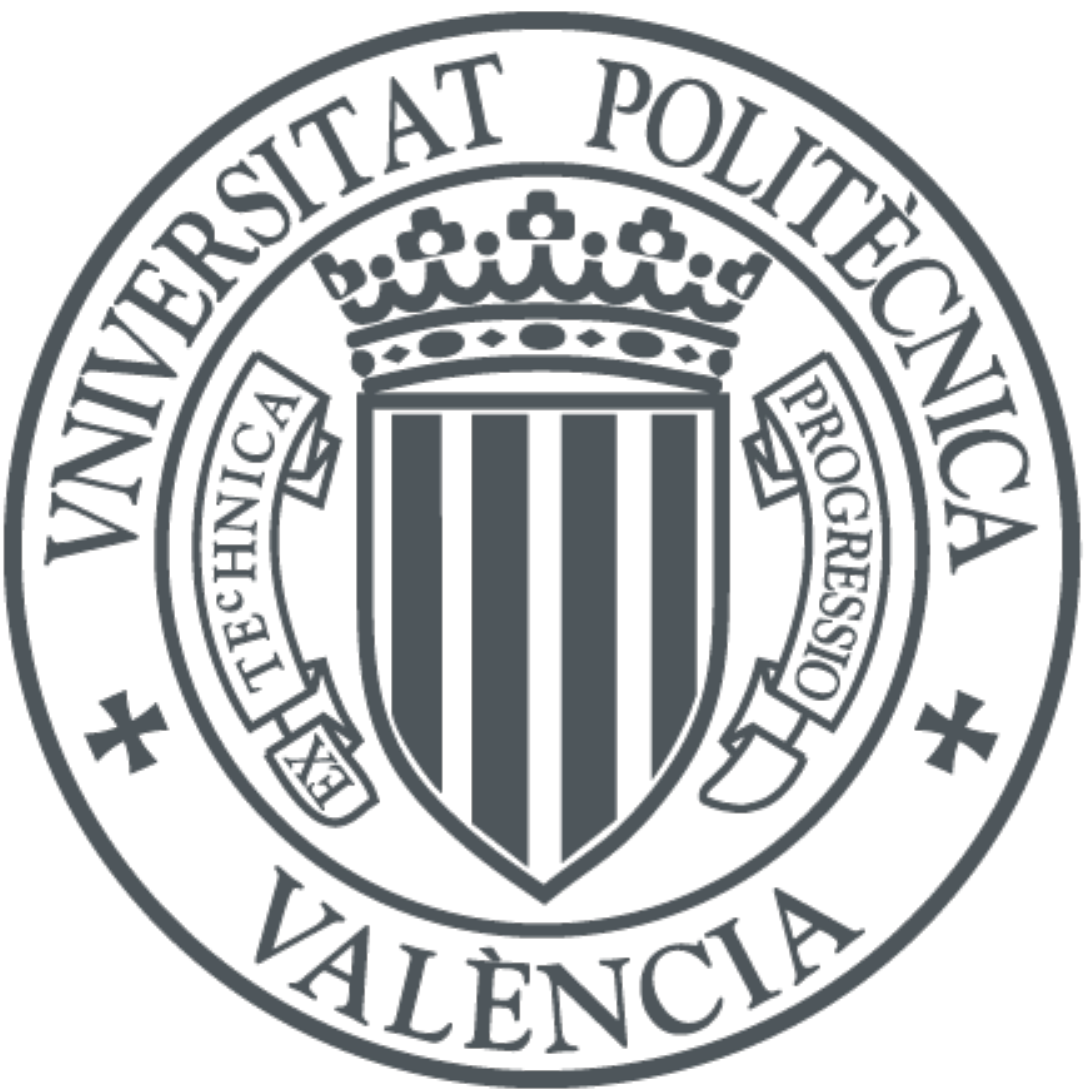

The final publication is available at

http://doi.org/10.1016/j.electacta.2018.11.212

Copyright Elsevier

Additional Information 


\title{
Electrochemical identification of painters/workshops: the case of Valencian Renaissance-Baroque painters (ca. 1550- ca. 1670)
}

Antonio Doménech-Carbó*a ${ }^{\mathrm{a}}$, María Teresa Doménech-Carbób ${ }^{\mathrm{b}}$ Amparo CastellóPalacios $^{\mathrm{b}}$, Vicent Guerola-Blay ${ }^{\mathrm{b}}$, Eva Pérez-Marín ${ }^{\mathrm{b}}$

a Departament de Química Analítica. Universitat de València. Dr. Moliner, 50, 46100 Burjassot (València) Spain.

${ }^{\mathrm{b}}$ Institut de Restauració del Patrimoni, Universitat Politècnica de València, Camí de Vera 14, 46022, València, Spain.

* Corresponding author: e-mail: antonio.domenech@uv.es

\begin{abstract}
The voltammetry of immobilized particles (VIMP) methodology was applied to discriminate the oil painting production of a series of seven painters/workshops that worked in Valencia (Spain) between ca. 1530 and ca. 1650. When submicrosamples used for cross-section FESEM/EDX analysis were attached to graphite electrodes in contact with aqueous acetate buffer, well-defined responses were obtained. The reductive processes of lead pigments (lead white and lead-tin yellow) overlapped those associated to the lead soaps and other species resulting from the pigment-oil binder interaction in the sample. Such responses, which are theoretically modeled, were sensitive to changes in paint type and dose and thus provided a painter/workshop-characteristic voltammetric response defining a usable electrochemical fingerprint for authorship assessments.
\end{abstract}

Keywords: Electrochemistry; Oil painting; Authorship discrimination; Lead pigments; Lead soaps. 


\section{Introduction}

Identifying the author of a painting is an essential task in heritage science and involves a stylistic analysis and a physico-chemical analysis [1-3]. This analytical target is constrained by major difficulties: the need to use minimally invasive or non destructive techniques, both the multicomponent chemical nature and multilayered structure of paintings and the occurrence of deteriorations and undocumented restorations. One way to characterize (and authenticate) the production by different painters is to analyze the components of paintings. This is based on the idea that each painter (or better 'workshop') used some specific components (pigments, binders, varnishes) and their combinations which can be identified by techniques of chemical analysis. This is normally accomplished by using the microsamples removed from the painting, which are mounted as cross-sections [4], along with a variety of non-invasive analytical techniques [5-7]. In general, binding media, varnishes and organic pigments have to be analyzed separately from inorganic components (pigments, dryers, stabilizers, etc.) [8].

One of the main problems for authorship investigation in paintings is that, in general, the number of samples has to be strictly limited to ensure the integrity of the oeuvre so that, frequently, sampling is confined to 1-3 spots. Taking into account these limitations, it is reported here an electrochemical methodology for authorship identification based on the re-use of cross-sections routinely used for spectral, image analysis, microscopy, etc. techniques [4,9]. The size of these samples was typically ca. $100 \mu \mathrm{m}$ and their mass was at the microgram level. In order to perform replicate voltammetric measurements, we used aliquots of such samples, in the following termed as sub-microsamples.

Electrochemical techniques have been traditionally applied to study corrosion on metallic heritage objects [10-14]. In this context, the voltammetry of immobilized particles (VIMP), a solid-state electrochemical methodology developed by Scholz et al. $[15,16]$, provides the opportunity to perform localized analyses with submicrogram amounts of sample attached to an inert electrode that comes into contact with a suitable electrolyte [17,18]. Initially applied to the identification of inorganic [19-23], organic [24-26] and hybrid [27] pigments in paintings and polychromed statuary, we recently discovered that the voltammetric response of electroactive pigments is influenced by 
deterioration processes [28,29], and also by the nature of the accompanying matrix in either wall painting [30] or oil painting [31,32].

Here we describe the use of the VIMP to identify of different painters based on the 'electrochemical fingerprint' that results from using different combinations of pigments and binding media. The proposed methodology was applied to a particularly difficult case: discriminating different painters who worked during a relatively narrow historical period, the transition from the Renaissance to the Baroque, in a restricted region, Valencia, east Spain. We studied samples from 12 oil paintings attributed to seven painters who worked between ca. 1550 and 1670, starting with Nicolás Borrás (15301610), and then moving on Vicent Castelló (ca. 1587-ca. 1636), Vicente Requena (ca. 1556-1605), Francisco Ribalta (1565-1628), Juan Ribalta (1596/1597-1628), Juan Sariñena (1545-1619), and ending with Jerónimo Jacinto de Espinosa (1600-1667), of relevant importance in the Spanish context $[33,34]$. The historical data indicate that Nicolás Borrás, Juan Sariñena and Vicente Requena on the one hand, and Francisco and Juan Ribalta (father and son, respectively), Vicent Castelló and Jerónimo Jacinto de Espinosa by the second one, were directly related/collaborated by the one hand, and between. The aims of the current electrochemical study are to discriminate between individual painters for authorship attribution and authentication purposes, and determine the relationships between them. Table 1 summarizes the characteristics of the studied oeuvres; whereas Figure 1a shows one of the most representative paintings: San Cristóbal de Licia by Vicente Requena (all paints are reproduced in Supplementary Information). The voltammetric analysis, concentrated in the response of lead pigments, used exclusively the sub-micro-remains of the samples extracted for the conventional optical microscopy (OM) and field emission scanning electron microscopy-X-ray microanalysis (FESEM-EDX) stratigraphic analyses carried out during the restoration tasks performed during the 2011-2017.

There was a series of obvious problems for the proposed analytical objective of discriminating between different painters/workshops: i) the composition of samples from different locations of the same paint can differ significantly in terms of the type and concentration of pigments; ii) the samples contained all the strata of the pictorial layers, including an imprimatura of lead white in some cases, and a ground layer made of gypsum, natural red earths or a combination of Mars colors and red earths, depending 
on the artist; iii) the materials of an artist/workshop may have varied throughout their carrier so that the earlier paintings could differ from those that data back to a later time; iv) the possibility of different painters intervening in several areas of the same oeuvre. Our hypothesis was that, in spite of these difficulties, each painter/workshop retained a voltammetric pattern that allowed its identification based on the analysis of the response of lead pigments and lead soaps (lead carboxylates with fatty acids), which can be described according to the studies of paint samples [19-32], and lead compounds [3538], and modeled by available theoretical descriptions of solid-state redox processes [39-42].

\section{Experimental}

\subsection{Samples.}

The sub-micro-remains of the samples excised from paintings for the conventional stratigraphic examination by OM and FESEM-EDX while performing the restoration tasks during the 2011-2017 period were used for the VIMP measurements with no further treatment.

\subsection{Instrumentation and methods.}

The electrochemical experiments were performed at $298 \mathrm{~K}$ in a three-electrode cell using a CH I660C device (Cambria Scientific, Llwynhendy, Llanelli, Wales, UK). Airsaturated aqueous $0.25 \mathrm{M}$ sodium acetate buffer (Panreac) at $\mathrm{pH} 4.75$ was used as a supporting electrolyte for the electrochemical measurements and was renewed after each electrochemical run to avoid contamination due to metal ions eventually being released to the solution phase during electrochemical turnovers. To test the possibility of using portable equipment, no deaeration was performed. Square wave voltammograms (SWVs) were recorded with sample-modified graphite electrodes, a platinum wire counter electrode and an $\mathrm{Ag} / \mathrm{AgCl}(3 \mathrm{M} \mathrm{NaCl})$ reference electrode completed the three-electrode arrangement.

The VIMP measurements were performed upon abrasive transference of submicrosamples previously used for cross-section microscopy analysis to graphite bars (Alpino-68 CH-type, Alpino ${ }^{\circledR}$, Barcelona, Spain; $2.0 \mathrm{~mm}$ diameter). The sample was deposited on the plane surface of an agate mortar and pressed with the pestle; then the 
lower end of the graphite electrode was gently rubbed over the sample following the usual VIMP protocol $[15,16]$. The sample-modified graphite bars were then placed in the electrochemical cell so that only the lower electrode end came into contact with the electrolyte solution.

The FESEM Zeiss (Orsay Physics Kleindiek Oxford Instruments) model Auriga compact equipment was used for the FESEM-EDX examination. The X-ray microanalysis was performed using an Oxford-X Max X-ray microanalysis system coupled to the FESEM controlled by Aztec software. A voltage of $20 \mathrm{kV}$ and a working distance of 6-7 $\mathrm{mm}$ were used.

FTIR spectroscopy was carried out using a Fourier transform infrared spectrometer VERTEX 70 (Bruker Optics), which includes a fast recovery deuterated triglycine sulfate (FRDTGS) temperature-stabilized coated detector and a MKII Golden Gate Attenuated Total Reflectance (ATR) accessory. Thrirty-two scans were collected at a resolution of $4 \mathrm{~cm}^{-1}$. The IR spectra were processed by the OPUS 7.2/IR software (Bruker Optik GmbH, Germany).

\section{Results and Discussion}

\subsection{Composition and stratigraphy.}

Based on the FESEM-EDX analysis of the paint strata, it was found that the paintings consisted of a base layer made of gypsum, or of mixtures of natural red earths and Mars red, and were optionally accompanied by an imprimatura containing lead white $\left(2 \mathrm{PbCO}_{3} \cdot \mathrm{Pb}(\mathrm{OH})_{2}\right)$. A number of pigments, namely, vermilion $(\mathrm{HgS})$, smalt (cobaltcontaining glass-type pigment), minium $\left(\mathrm{Pb}_{3} \mathrm{O}_{4}\right)$, azurite $\left(2 \mathrm{CuCO}_{3} \cdot \mathrm{Cu}(\mathrm{OH})_{2}\right)$, verdigris $\left(\mathrm{Cu}\left(\mathrm{CH}_{3} \mathrm{COO}\right) \cdot \mathrm{Cu}(\mathrm{OH})_{2}\right)$, ochres, red earths, Sienna, umber (all containing $\mathrm{Fe}_{2} \mathrm{O}_{3}$ and $\mathrm{FeO}(\mathrm{OH})$ in different degrees of hydration and crystallinity) and bone black, were identified in the different locations of the paintings. Apart from the ubiquitous presence of lead white in the imprimatura, lead white and lead-tin yellow $\left(\mathrm{PbSnO}_{4}\right)$ were detected in the yellow and green areas. Figure 1 shows a photographic image of the

painting San Cristóbal de Licia by Vicente Requena (a) accompanied by a microphotograph of the cross-section of the SCR2 sample excised from a greenish area of the painting. Here, we can distinguish successive white and red preparative layers for which the EDX analysis denoted the use of gypsum (g) and a mixture of red earths plus 
lead white (r), respectively. The pictorial outer greenish paint layer is composed mainly of lead white and also contains grains of yellow and green pigments. The X-ray spectrum (Figure 1c) of the yellow pigment shows the $\mathrm{Pb}$ and $\mathrm{Sn} \mathrm{X}$-ray emission lines, displaying the typical lead-tin yellow pigment profile. The $\mathrm{Cu}$ emission lines, also present in the X-ray spectrum, are ascribed to the surrounding grains of green pigment.

\subsection{Voltammetric response.}

Figure 2a,b shows the SWVs of sample SNJ11 from a flesh of the Sueño del Niño Jesús by Vicent Castelló, attached to graphite electrodes in contact with air-saturated $0.25 \mathrm{M}$ $\mathrm{HAc} / \mathrm{NaAc}$ aqueous solution, $\mathrm{pH}$ 4.75. When scanning the potential in the negative direction, a series of cathodic waves between 0.20 and $-0.80 \mathrm{~V}$ vs. $\mathrm{Ag} / \mathrm{AgCl}$ appear, with a more prominent signal at ca. $-0.60 \mathrm{~V}$. Such signals are preceded by the current at ca. $1.2 \mathrm{~V}$, which corresponds to the hydrogen evolution reaction (OER, note that in the SWVs, cathodic and anodic signals can simultaneously appear in the same scan), followed by the hydrogen evolution process (HER) at more negative potentials. The subsequent positive-going voltammogram is dominated by a tall anodic peak at -0.50 V. This voltammetric response can be described according to prior studies into paint samples [19-32], and lead compounds [35-38], to the reduction of earth pigments, which are responsible for the waves from $0.20 \mathrm{~V}$, and lead white, that yielded the signal at $-0.60 \mathrm{~V}(\mathrm{C}(\mathrm{Pb}))$, whose presence is confirmed by the characteristic stripping peak at $-0.50 \mathrm{~V}(\mathrm{~A}(\mathrm{~Pb}))$ in Figure $2 \mathrm{~b}$, which corresponds to the oxidation of the lead metal deposits formed during lead white reduction. The cathodic signals overlap the illdefined wave that corresponds to the reduction of dissolved oxygen which appears ca. $-0.70 \mathrm{~V}$.

Figure 2c,d shows the corresponding voltammograms for sample SJP3 taken from the green robe of the San Jerónimo Penitente by Joan Borrás. Here, cathodic signals at $-0.10 \mathrm{~V}$ and $-0.48 \mathrm{~V}$ are recorded in the negative-going voltammogram (Figure 2c). These signals are attributable to the reduction of copper pigment and lead-tin yellow, respectively, with concomitant oxidation peaks at $0.05 \mathrm{~V}$ and $-0.45 \mathrm{~V}$.

Our data confirm the common presence of lead white in the flesh of the studied paintings and the use of lead-tin yellow (displaying Sn peaks in the X-ray spectra of 
pictorial strata, see Figure 1), often accompanied by lead white, in the yellow, green and even the blue areas of the paintings. In the green and blue regions, copper pigments were detected.

Remarkably, by semi-derivative data convolution, the cathodic signals corresponding to the reduction of lead pigments resolve into different signals, as can be seen in Figure 3, in which the region between -0.20 and $-1.00 \mathrm{~V}$ of the SWVs of several yellow and green samples is depicted. The cathodic profile exhibits significant variability from one sample to another, but also certain regularities. Thus the voltammograms of samples IN3 (Figure 3a) and IN8 (Figure 3b), which correspond to two different green areas on the Inmaculada Concepción by Juan Sariñena, show a clear similarity, but differ from green samples NSJ6 (Figure 3c) from the Nacimiento de San Juan by Jerónimo Jacinto de Espinosa, SNJ9 from El Sueño del Niño Jesús by Vicent Castelló (Figure 3d) which, in turn, differ from the voltammograms of yellow samples EH1 (Figure 3d) and SP3 (Figure 3e) that respectively correspond to the Ecce Homo by Francisco Ribalta, and San Pedro Llorando by Juan Ribalta. The above data suggest the possibility of attributing a characteristic voltammetric profile to each painter. Consistently, the voltammograms for samples EH5 and SP6 in Figure 3d, which correspond to the paintings by Ribalta father and son, respectively, more closely resemble one to another.

\subsection{Electrochemical processes.}

To streamline the possibility of electrochemically characterizing painters/workshops, the electrochemistry of lead pigments in paint samples has to be interpreted in the light of available modeling for the solid-state redox processes involving ion-insertion solids [39-42]. Solid-state reductive processes involve the coupled ingress of protons from the electrolyte and electrons from the base electrode. The main cathodic signal can be described as the reduction of the grains of pigment which are in contact with the graphite surface and the electrolyte solution. Blank experiment on microparticulate deposits of lead white pigment, which does not dissolved in contact with acetate buffer at $\mathrm{pH} 4.75$, produced a response comparable to that described for litharge $(\mathrm{PbO})$ $[36,37]$, so that for lead white the reduction process can be formulated as follows:

$$
\left\{\mathrm{Pb}_{3}\left(\mathrm{CO}_{3}\right)_{2}(\mathrm{OH})_{2}\right\}_{\text {solid }}+4 \mathrm{H}^{+} \text {aq }+6 \mathrm{e}^{-} \rightarrow 3\{\mathrm{~Pb}\}_{\text {solid }}+2 \mathrm{HCO}_{3}{ }^{-} \text {aq }+4 \mathrm{H}_{2} \mathrm{O}
$$


This is a conversion of basic lead carbonate to metallic lead, as described for the solidstate reduction of several lead compounds [36,37].

Upon semi-derivative deconvolution, the voltammograms, however, show at least three overlapping peaks (see Figure 3). These voltammetric features can be attributed to the superposition of the signals for the reduction of two lead pigments (lead white and leadtin yellow), but also to the reduction of lead soaps and other lead complexes as a result of the pigment and oil binding medium interaction. Figure 4 shows a FESEM image of a cross-section of the Ecce Homo painting by Francisco Ribalta. Here, we can distinguish a coarse grain of lead white surrounded by a dark grey envelope of amorphous saponified materials, similarly to that described in the literature $[43,44]$.

The role of lead in oil paintings, studied after adding lead acetate trihydrate to mastic varnish, has been recently discussed by de Viguerie et al. [45] in terms of it promoting the radical generation related to oxidative radical chain reactions. The formation of such $\mathrm{Pb}$ (II)-carboxylate complexes was confirmed by the ATR-FTIR examination of the paint samples, where asymmetric stretch bands of the -COO group at 1517 (lead palmitate) and $1541 \mathrm{~cm}^{-1}$ (lead stearate) [46-48] were detected, and accompanied characteristic lead white or hydrocerussite $\left(2 \mathrm{PbCO}_{3} \cdot \mathrm{Pb}(\mathrm{OH})_{2}\right)$ bands [43] at $1407 \mathrm{~cm}^{-1}$ ( $v_{3}$ stretch of the carbonate group) and 3535 (shoulder, stretch of the $\mathrm{OH}$ group), 1040, 778 and $676 \mathrm{~cm}^{-1}$. IR bands at $1703\left(\mathrm{C}=\mathrm{O}\right.$ stretch) and $1098 \mathrm{~cm}^{-1}$ (stretch of the $\mathrm{C}-\mathrm{O}$ group) of the released fatty acids. The gypsum bands at 3521, 3398 (sh, stretch $\mathrm{OH}$ group), 1151 ( $v_{3}$ stretch of the sulfate group), 1620 (bending of the OH group), 676 and $600 \mathrm{~cm}^{-1}$ ( $v_{4}$ bending of the sulfate group) were also present in the spectrum (see Figure S.1 in the Supplementary Information).

These identified metal soaps are complexes that originate from the lead ions released from cerussite $\left(\mathrm{PbCO}_{3}\right)$ or hydrocerussite and the long-chain saturated fatty acids formed by a partial hydrolysis of the network of polymerized drying oil. These complexes can migrate and form aggregates that protrude from the surface of the paint. In several cases (see Figure S.2 in the Supplementary Information,), a detailed examination of the region between 1500 and $1600 \mathrm{~cm}^{-1}$ revealed the presence of a band at $1590 \mathrm{~cm}^{-1}$ attributed to the lead carboxylate complexes (asymmetric stretch COO- 
group) presumably results from the overlapping of the individual bands ascribed to the $\mathrm{Pb}, \mathrm{Mn}$ and $\mathrm{Ca}$ carboxylate complexes from lead white and red earths that form a polyelectrolyte layer around the pigment grains $[43,44]$.

Accordingly, the peak splitting that appears in the reduction of lead pigments in the paint samples can be described in terms of the superposition of different processes [49]. Consistently, the synthetic paint specimens prepared from lead pigments and linseed oil produced voltammograms with cathodic peak splitting (see Figure S.3 in the Supplementary Information). The electrochemical reduction of lead soaps can be formulated as:

$$
\left\{\mathrm{Pb}^{2+}\left(\mathrm{RCOO}^{-}\right)_{2}\right\}_{\text {soap }}+2 \mathrm{H}^{+} \text {aq }+2 \mathrm{e}^{-} \rightarrow\{\mathrm{Pb}\}_{\text {solid }}+2 \mathrm{RCOOH}
$$

Such soaps will, in principle, form a layer around the pigment grains and, when they come into contact with the aqueous electrolyte, they may form a polyelectrolyte layer by ultimately releasing $\mathrm{Pb}^{2+}$ ions, which, in turn, are electrochemically reduced to lead metal. Accordingly, the overlapping of the different reductive processes results in the multiple peak cathodic response of the paint samples, a phenomenon also observed in the CdS-based [50] and verdigris-based [51] paint-type films. Figure 5 shows a simplified scheme to interpret the lead-based electrochemistry of the paint samples consisting in pigment grains surrounded by lead soaps embedded into a binder (plus other components) matrix.

For our purposes, the relevant point we wish to emphasize is that, even thought the sampling process and paint dose can vary from one location of the paint to another, each painter/workshop produced individual preparative patterns, as reflected in subtle, but detectable details in the voltammetric response. As the sampling process cannot be limited to either individual pigment grains or the pictorial layer, the voltammograms are dominated by lead white reduction, which is common for all the preparative layers and most pictorial layers, accompanied by lead-tin yellow in the yellow and green areas. Both lead pigments display a similar voltammetric response (see the ELCHER database) [32], consisting of a prominent cathodic peak at ca. $-0.60 \mathrm{~V}$ in acetate buffer. 
As seen for the yellow and white areas, and also for the green samples (see Figure 3), the voltammetry of the paint samples is dominated by the reduction of lead pigments accompanied by the aforementioned processes associated with the pigment-binder interaction, which once again suggests the possibility of discriminating between painters/workshops (see Figure S.4 in the Supplementary Inofrmation). These considerations can also be extended to the flesh samples (see Figure S.5 in the Supplementary Inofrmation) where the profile in the region between 0.0 and $-1.0 \mathrm{~V}$, which herein contains similar (in peak current terms) contributions of earths and lead white, displays differences between different painters.

\subsection{Electrochemical characterization of painters/workshops.}

The above data suggest that each painter/workshop used a different dose of pigment(s) plus a binder, resulting in a characteristic voltammetric profile associated with the reduction of the lead-containing components (mainly lead pigment(s) plus lead soaps). A detailed examination of the SWVs of the samples and the synthetic paint specimens indicated that the peak potentials for the different signals present shifts that can be attributed to the effect of more or less increased ohmic drops given the insulating nature of the binder that embeds the pigment grains. This effect agrees with previous studies into $\mathrm{CdS}$ and verdigris specimens [50,51]. Accordingly, to characterize the different workshops, the cathodic wave $\mathrm{C}(\mathrm{Pb})$ is resolved into four cathodic signals in the negative-going SWVs after semi-derivative convolution. The first signal (II), which appears at ca. $-0.50 \mathrm{~V}$, is attributable to the reduction of $\mathrm{Pb}^{2+}$ ions released from the polyelectrolyte layer that resulted from the electrolyte-lead soaps interaction; the next signals, appearing at ca. -0.55 (I) and $-0.65 \mathrm{~V}$ (III), correspond to the reduction of the lead pigments and lead soaps, respectively, as judged upon comparison with blank voltammograms at pigment-modified graphite electrodes. The last signal (IV) consists of a shoulder at ca. $-0.75 \mathrm{~V}$ and can be considered as representative of the contribution of the earths to form a more or less intense background [21,22,28]. The criteria adopted to identify the above signals and to measure the corresponding currents, $i(\mathrm{~J})(\mathrm{J}=1$ to 4$)$, are provided as a Supplementary Information (Figure S.6). However, as far as the net amount of the sample transferred to the graphite electrode surface cannot be controlled, which is characteristic of VIMP [15-18], these currents cannot be reproduced in replicate experiments. 
In order to characterize the existence of possible artist-characteristic voltammetric patterns, we tested the grouping possibility with multivariate strategies, but both the principal component analysis (PCA) and hierarchical cluster analyses (HCA) that used the entire matrix of the $i(\mathrm{~J})$ currents (see Figure S.7 in the Supplementary Information) were unsuccessful. One possible reason for this might be because, as will be theoretically modeled (vide infra), there are nonlinear relationships between the measured currents which, thus, results in distorted normalizations.

In spite of this difficulty however, clear regularities can be found in the voltammetric response. First of all, there is a linear relationship between the peak currents recorded for the cathodic signal $\mathrm{C}(\mathrm{Pb})$ and the lead stripping, $\mathrm{A}(\mathrm{Pb})$, as can be seen in Figure 6a. These signals correspond to the overall lead-centered electrochemical processes recorded in negative-going (Fig. 2a,c) and positive-going (Fig. 2b,d) potential scan voltammograms. This feature reflects a clear statistical correlation between the reduction of all lead compounds (unresolved signal $\mathrm{C}(\mathrm{Pb})$, roughly equivalent to the sum of signals I-IV) and the subsequent oxidation of the corresponding lead metal deposit (signal $\mathrm{A}(\mathrm{Pb})$ ). In contrast, when plotting (see also Fig. 6a) the extreme current that corresponds to the OER in the same voltammograms (Fig. 2) vs. A(Pb), no apparent correlation appears. This feature is just that expected for a process (OER) which, under our experimental conditions, should be independent on the type of sample attached to the electrode. The regression analysis and $F$-statistics reveal a relatively high degree of correlation between $\mathrm{C}(\mathrm{Pb})$ and $\mathrm{A}(\mathrm{Pb})$ (relatively high $r$ and $F$ values, and a moderate sum $(s)$ of residual squares), unlike the correlation between $\mathrm{OER}$ and $\mathrm{A}(\mathrm{Pb})$, characterized by low $r$ and $F$ values.

When peak current data for lead-centered processes were tested, an apparent almost randomized response was obtained. This can be seen in Figure $6 b$, in which the values of $i$ (II) are plotted vs. the values of $i$ (III) recorded in deconvoluted voltammograms such as in Figure 3 for yellow, green and white samples in this study. The possible correlation between these parameters was characterized by low $r$ and $F$ values and a considerably high value of $s$, thus denoting the lack of functional dependence between them. 
However, when the experimental data for the different painters are individualized, these appear grouped into well-defined tendency lines. This can be seen in Figure $6 \mathrm{c}$, where the data points for Nicolás Borrás, Juan Sariñena and Vicente Requena in Figure 6b have been separated, and in Figure 6d, where data points for Jerónimo Jacinto de Espinosa, Francisco Ribalta and Juan Ribalta in Figure 6b have been individualized. Correlation coefficients for fitting the different sets of data to a potential function are relatively high (see values inserted in Fig. 6c,d), thus denoting an in principle satisfactory grouping of such data into different tendency lines. Additional data are provided as Supplementary information, Figure S.7.

\subsection{Theoretical modeling}

The above tendency curves can be modeled on the basis of the theoretical description of solid state redox processes due to Lovric, Scholz, Oldham and coworkers to describe the electrochemistry of the so-called ion-insertion solids consisting of solid-to-solid topotactic conversions [38-42]. Although the reduction of lead pigments to lead metal involves a more complicated reaction scheme, it seems reasonable to adopt similar basic hypotheses than in this modeling. Accordingly, it will be assumed that the soaps form a layer of thickness $\delta$ surrounding the pigment grains and that the formation of the soaps follows a potential kinetic law, frequent in solid-state chemical and electrochemical reaction processes [52-54]. The essential ideas are:

i) The electroactive pigment grains are embedded into a matrix of binder, in principle, non-electroactive, and surrounded by a more or less thin layer of lead soaps often incorporating a polyelectrolyte layer.

ii) The reduction of solid lead species to lead metal involves the insertion of protons from the electrolyte coupled to electron transfer from the base electrode so that the electrochemical process, as schematized in Figure 4, initiates at the solid/electrolyte/base electrode three-phase junction.

iii) According to the aforementioned model, the peak currents can be taken as proportional to the perimeter of the three-phase boundary, as theoretically obtained by Schröder et al. [42]. Due to the nature of the abrasive sampling used in VIMP 
measurements, in each individual experiment, there is a different distribution of grains in contact with the base electrode.

This last situation is schematized in Figure $7 \mathrm{a}$ for two spheroid pigment grains embedded into an insulating matrix partially exposed to the electrolyte (see also Figure 4). Assuming that in an individual experiment there is an averaged fraction $f$ of spheroid pigment grains of radius $r$ surrounded by a lead soaps layer of thickness $\delta$ exposed to the electrolyte/base electrode junction, the peak current for the reduction of the pigment, $i(\mathrm{I})$ and the lead soaps, $i(\mathrm{III})$, can be expressed as:

$$
\begin{gathered}
i(\mathrm{I})=g_{\mathrm{I}} f(2 \pi r) \\
i(\mathrm{III})=g_{\mathrm{III}} f[2 \pi(r+\delta)]
\end{gathered}
$$

where $g_{\mathrm{I}}$ and $g_{\mathrm{III}}$ are the respective electrochemical coefficients of response of the pigment and the lead soaps. These coefficients depend on the electrolyte, potential scan rate and the type of pigment and binder, but are independent on the radius of the pigment grain. In principle, the fraction of grains exposed to the electrolyte can be considered as dependent on the concentration and uniformity of distribution of the pigment grains in the paint specimen and, for simplicity, can be considered as a constant for each painter when homologue areas (yellow, white, green, flesh) are compared. The thickness of the soaps layer, however, can vary significantly depending on the extent of the attack of the binder to the pigment. This attack can be viewed from the perspective of solid-state reaction kinetics [52-54]. Among other possibilities, we can consider the case in which the net amount of released lead was proportional to a potential function of the pigment amount. This means that the mass of lead soaps, $m_{\text {soap }}$, can be expressed as a function of the mass of pigment, $m_{\text {pigment }}$, as:

$$
m_{\text {soap }}=k m_{\text {pigment }}^{\alpha}
$$

introducing a rate constant $k$. Then, the thickness of the soap layer can be related with the radius of the spheroidal particle pigment by:

$$
\frac{4}{3} \pi \rho_{\text {soap }}\left[(r+\delta)^{3}-r^{3}\right]=k\left(\frac{4}{3} \pi \rho_{\text {pigment }} r^{3}\right)^{\alpha}
$$


$\rho_{\text {pigment, }} \rho_{\text {soap }}$, being the densities of the pigment and the lead pigment soap. When $\delta<<$ $r$, one can approximate:

$$
\delta \approx \frac{k}{3}\left(\frac{\rho_{\text {pigment }}^{\alpha}}{3 \rho_{\text {soap }}}\right)\left(\frac{4}{3} \pi\right)^{\alpha-1} r^{3 \alpha-2}
$$

Accordingly, one can predict a variation of i(III) on i(I) given by:

$$
i(\mathrm{III}) \approx \frac{g_{\text {III }}}{g_{\mathrm{I}}}\left(i(\mathrm{I})+\frac{k}{3}\left(\frac{\rho_{\text {pigment }}^{\alpha}}{\rho_{\text {soap }}}\right) \frac{(4 \pi / 3)^{\alpha-1}}{\left(2 \pi f g_{\mathrm{I}}\right)^{3 \alpha-1}} i(\mathrm{I})^{3 \alpha-2}\right)
$$

or, equivalently,

$$
\frac{i(\mathrm{III})}{i(\mathrm{I})} \approx \frac{g_{\mathrm{III}}}{g_{\mathrm{I}}}\left(1+G i(\mathrm{I})^{3(\alpha-1)}\right)
$$

were $G=\left(k / 3^{\alpha} 2^{1+\alpha} \pi^{2 \alpha} f^{3 \alpha-1} g_{\mathrm{I}}^{3 \alpha-1}\right)\left(\rho_{\text {pigment }}^{\alpha} / \rho_{\text {soap }}\right)$. Figure $7 \mathrm{~b}$ compares different theoretical lines for different $\alpha$ values using Eq. (9) taking $g_{\mathrm{III}} / g_{\mathrm{I}}=0.10$ and $G=0.10$ all leading to values of $i(\mathrm{III}) / i(\mathrm{I})$ increasing with $i(\mathrm{I})$. Such curves can be satisfactorily approximated to those resulting from several experimental data in Figure 6. A second set of such experimental data, those consisting of values of $i(\mathrm{III}) / i(\mathrm{I})$ decreasing with $i(\mathrm{I})$, can also be described by Eq. (9) as can be seen in Figure 7c, where the theoretical lines for different $\alpha$ values taking as before $g_{\mathrm{III}} / g_{\mathrm{I}}=0.10$ but adopting a larger $k$ value providing $G=100$. The above treatment ignores the possible contribution of the background current, in particular that due to the reduction of dissolved oxygen (oxygen reduction reaction, ORR) occurring at ca. $-0.75 \mathrm{~V}$ at graphite electrodes under our experimental conditions. This correction can easily be introduced in the above treatment as presented as a Supplementary Information, without alteration of the essential aspect: the possibility of predicting potential variations of $i(\mathrm{III})$ on $i(\mathrm{I})$ sensitive to the values of the $\alpha$ exponent.

\subsection{Discussion}

For identification purposes, it is convenient to use the variation of the ratio of the peak currents of III and II, $i(\mathrm{II}) / i(\mathrm{III})$, on the peak current for the signal III, $i(\mathrm{III})$. The intensity of the deconvoluted voltammetric signals can be used in general to quantify 
different species, in particular those remaining electrode-confined, as described for the oxidation of $\mathrm{CO}$ adsorbed at $\mathrm{Pt} / \mathrm{C}$ electrode [55]. Figure 8 shows $i(\mathrm{II}) / i(\mathrm{III})$ vs. $i(\mathrm{III})$ plots for samples taken in yellow and green areas (empty figures) and white plus flesh areas (solid figures) of the paintings of: a) Jerónimo Jacinto de Espinosa, b) Nicolás Borrás, c) Juan Sariñena, d) Francisco Ribalta (squares), Juan Ribalta (triangles) and Vicent Castelló (rhombs). In all cases, experimental data showed a satisfactory fit to the predictions from Eq. (9) (or equivalently, Eq. (8)); correlation coefficients for the fit of each series of data to a potential function have been inserted in Figure 8 while pertinent statistical parameters associated to the determination of the parameters $\left(g_{\mathrm{III}} / g_{\mathrm{I}}\right) G$ and $\alpha$ in Eq. (9) are summarized in Table 2. It is convenient to underline that:

a) In the cases where samples provide from more than one painting by the same author, experimental data points fall in the same tendency curve. These are the cases of Jerónimo Jacinto de Espinosa (4 paints), Nicolás Borrás (2 paints) and Francisco Ribalta (2 paints).

b) Each painter displays different tendency lines for flesh and white samples, all containing lead white, and yellow-green areas, where lead-tin yellow was often accompanied by lead white and copper pigments.

c) There is possibility of justifying the grouping of experimental data in different tendency curves (Figs. 6 and 8) on the basis of a relatively simple theoretical model derived from the known electrochemistry of lead pigments [31,32,35-37] and the modeling of VIMP processes [38-42].

It is pertinent to note that the theoretical modeling in section 3.5 supports the absence of satisfactory grouping based on PCA and HCA methods. As can be seen in Figure 6b, samples from all painters displaying low $i$ (II) and $i$ (III) currents fall in a common region of the $i$ (II) vs. $i$ (III) diagram and differences between different painters become pronounced when relatively large values of such currents are obtained. This can be rationalized on assuming that the samples producing low currents are those containing small pigment grains and hence containing relatively small amounts of lead soaps whereas samples containing relatively large pigment grains will provide more extensive formation of lead soaps. Since the differences between the painters/workshops can be mainly attributed to those in the pigment-binder interaction, such differences are increased on increasing the size of the pigment grains (and consequently the $i$ (II), $i$ (III) 
currents), as indicated in Eq. (7). Roughly, each painter is characterized by the nonlinear variation in the formation of lead soaps relative to the size pigment grain that results in characteristic tendency curves (given by Eqs. (8) and (9)) such as in Figures 6 and 8 .

It is pertinent to note that, consistently with the hypothesis of an electrochemical individualization of painters, data points for Juan Ribalta and Vicent Castelló, the former son of Francisco Ribalta and both their disciples, fall in common tendency curves (Figure 6d), thus denoting that there was continuity in the materials and dosages of the workshop.

The relevant point to emphasize is that, assuming that the values of $\rho_{\text {pigment }}, \rho_{\text {soap }}$, and $f$ are essentially the same in all paints, the obtained curves are strongly sensitive to the variations in the values of $k$ and $\alpha$. As far as the value of these parameters for a given pigment depends mainly on the type of binder and the pigment/binder dosage (and possibly by the presence of other pigments), even subtle differences in these properties of the paint specimens can be reflected in sharply different $i(\mathrm{III}) / i(\mathrm{I})$ vs. $i(\mathrm{I})$ curves, thus providing a method for discriminating painters/workshops. Table 2 summarizes the parameters derived from Eq. (9) usable for distinguishing the different painters/workshops in this study.

Interestingly, the above data can also be used for testing possible relationships between the different workshops. In fact, historical data, graphically summarized in Figure 9, indicate that Nicolás Borrás and Juan Sariñena influenced Vicente Requena, whereas Francisco Ribalta influenced directly his son Juan Ribalta and Vicent Castelló [33,34]. The two-dimensional diagram in Figure 9, plotting the values of the parameters $\log G$ and $\alpha$ determined from the fitting of experimental data to Eq. (9), reveals that not only each painter falls in a different region, enabling satisfactory discrimination among them, but that the historically related painters are grouped in two separate regions of the diagram. Electrochemical data denoted that, in agreement with historical data [33,34], two groups of directly related artists operated: the first one constituted by Nicolás Borrás, Juan Sariñena, Vicente Requena and the second, formed by Francisco Ribalta, Juan Ribalta, Vicent Castelló, and Jerónimo Jacinto de Espinosa. For our purposes, the relevant point to emphasize is that the proposed methodology can be used to 
complement existing methodologies for discriminating different painters/workshops and establishing connections between them. Ideally this could be expanded to distinguishing repaints or different authorship in the same painting and discriminate different periods in the production of a given artist.

\section{Conclusions}

The solid-state voltammetry of sub-microsamples used for conventional SEM-EDX analysis of cross-sections of oil paintings from seven workshops operating in Valencia (Spain) between ca. 1530 and ca. 1650 produced well-defined responses dominated by the reduction of lead pigments (lead white and/or lead-tin yellow). Such processes were accompanied by that due to the reduction of other pigments (mainly earths and copper pigments) and presented signal splitting associated to the reduction of lead soaps and released $\mathrm{Pb}^{2+}$.

The profile of the region of voltammograms where the reduction of the different lead species occurs varied significantly between samples excised from yellow and green areas and white and flesh areas in the paintings, and exhibited different patterns which define an 'electrochemical fingerprint' which can be attributed to the different type of pigments and particularly to the dosage of the oil binder plus pigment mixture used as a pictorial layer by the different artists. Although the complete identification of authorship is a complex task in principle requiring multi-technique approaches, the reported results provide a methodology complementing existing ones and illustrate the capability of voltammetric techniques to provide analytical information for the study and preservation of cultural heritage.

Acknowledgements: Project CTQ2017-85317-C2-1-P, supported with Ministerio de Economía, Industria y Competitividad (MINECO), Fondo Europeo de Desarrollo Regional (ERDF) and Agencia Estatal de Investigación (AEI), is gratefully acknowledged. The authors wish also to thank Mr. Manuel Planes and Dr. José Luis Moya, technical supervisors of the Electron Microscopy Service of the Universitat Politècnica de València. 
[1] P. Sohm, Palettes as Signatures and Encoded Identities in Early-Modern SelfPortarits. Art Hist. 40 (2017) 995-1025.

[2] S. Daniilia, E. Minopoulou, K.S. Andrikopoulos, I. Karapanagiotis, G.A. Kourouklis, Evaluating a Cumaean Sibyl: Domenichino or later? A multi analytical approach. Anal. Chim. Acta 611 (2008) 239-249.

[3] Burgio, L.; Clark, R. J. H.; Sheldon, L.; Smith, G. D. Pigment Identification by Spectroscopic Means: Evidence Consistent with the Attribution of the Painting Young Woman Seated at a Virginal from Vermeer. Anal. Chem. 77 (2005) 1261-1267.

[4] E. Pouyet, A. Lluveras-Tenorio, A. Nevin, D. Saviello, F. Sette, M. Cotte, Preparation of thin-sections of painting fragments: Classical and innovative strategies. Anal. Chim. Acta 822 (2014) 51-59.

[5] F. Rosi, C. Miliani, R. Braun, R. Harig, D. Sali, B.G. Brunetti, A. Sgamellotti, Noninvasive Analysis of Paintings by Mid-infrared Hyperspectral Imaging. Angew. Chem. Int. Ed. 5 (2013) 5228-5261.

[6] A. Polak, T. Kelman, P. Murray, S. Marshall, D.J.M. Stothard, N. Eastaugh, F. Eastaugh, Hyperspectral imaging combined with data classification techniques as an aid for artwork authentication. J. Cult. Herit. 26 (2017) 1-11.

[7] A. Daveri, S. Paziani, M. Marmion, H. Harju, A. Vidman, M. Azzarelli, M. Vagnini, New perspectives in the non-invasive, in situ identification of painting materials: The advanced MWIR hyperspectral imaging. Trends Anal. Chem. 98 (2018) 143-148.

[8] M.T. Doménech-Carbó, Novel analytical methods for characterising binding media and protective coatings in artworks. Anal. Chim. Acta 621 (2008) 109-139.

[9] D. Lau, C. Villis, S. Furman, M. Livett, Multispectral and hyperspectral image analysis of elemental and micro-Raman maps of cross-sections from a 16th century painting. Anal. Chim. Acta 610 (2008) 15-24.

[10] M. Serghini-Idrissi, M.C. Bernard, F.Z. Harrif, S. Joiret, K. Rahmouni, A. Srhiri, H. Takenouti, V. Vivier, M. Ziani, Electrochemical and spectroscopic characterizations of patinas formed on an archaeological bronze coin. Electrochim. Acta 50 (2005) 4699-4709.

[11] H. Antony, S. Perrin, P. Dillmann, L. A. Chaussé, Legrand, Electrochemical study of indoor atmospheric corrosion layers formed on ancient iron artefacts. Electrochim. Acta 51 (2005) 745-753.

[12] C. Chiavari, K. Rahmouni, H. Takenouti, S. Joiret, P. Vermaut L. Robbiola, Composition and electrochemical properties of natural patinas of outdoor bronze monuments. Electrochim. Acta 52 (2007) 7760-7769. 
[13] M.C. Bernard, S. Joiret, Understanding corrosion of ancient metals for the conservation of cultural heritage. Electrochim. Acta 54 (2009) 5199-5205.

[14] V. Flexer, R. Grayburn, M. de Keersmaecker, E.A.A. Mohammed, M.G. Dowsett, A. Adriaens, A New Strategy for Corrosion Inhibition Coatings for Lead Heritage Metal Objects. Electrochim. Acta 179 (2015) 441-451.

[15] F. Scholz, B. Meyer, B. Voltammetry of solid microparticles immobilized on electrode surfaces, Electroanalytical Chemistry, A Series of Advances, A.J. Bard, I. Rubinstein, Eds., Marcel Dekker, New York, 1998, vol. 20, pp. 1-86.

[16] F. Scholz, U. Schröder, R. Gulabowski, A. Doménech-Carbó, Electrochemistry of Immobilized Particles and Droplets, $2^{\text {nd }}$ edit. Springer, Berlin-Heidelberg, 2014.

[17] A. Doménech-Carbó, J. Labuda, F. Scholz, Electroanalytical chemistry for the analysis of solids: characterization and classification (IUPAC Technical Report). Pure Appl. Chem. 85 (2013) 609-631.

[18] A. Doménech-Carbó, M.T. Doménech-Carbó, V. Costa, Electrochemical Methods in Archaeometry, Conservation and Restoration, Monographs in Electrochemistry Series, F. Scholz, Edit. Springer, Berlin-Heidelberg, 2009.

[19] A. Doménech-Carbó, M.T. Doménech-Carbó, M. Moya-Moreno, J.V. GimenoAdelantado, F. Bosch-Reig, Identification of inorganic pigments from paintings and polychromed sculptures immobilized into polymer film electrodes by stripping differential pulse voltammetry. Anal. Chim. Acta 407 (2000) 275-289.

[20] A. Doménech-Carbó, M.T. Doménech-Carbó, J.V. Gimeno-Adelantado, F. BoschReig, M.C. Saurí_Peris, M.J. Casas-Catalán, Electrochemical analysis using charge transfer coefficient/peak potential diagrams of the alteration in copper pigments from microsamples of baroque wall paintings attached to polymer film electrodes. Fresenius J. Anal. Chem. 369 (2001) 576-581.

[21] A. Doménech-Carbó, M.T. Doménech-Carbó, J.V. Gimeno-Adelantado, F. BoschReig, M.C. Saurí_Peris, S. Sánchez-Ramos, Electrochemistry of iron oxide pigments (earths) from pictorial microsamples attached to graphite/polyester composite electrodes. Analyst 126 (2001) 1764-1772.

[22] T. Grygar, P. Bezdicka, D. Hradil, A. Doménech-Carbó, F. Marken, L. Pikna, G. Cepria, Voltammetric analysis of iron pigments. Analyst 127 (2002) 1100-1107.

[23] L.M. Moretto, F. Montagner, R. Ganzerla, P. Ugo, Nafion ${ }^{\circledR}$ as advanced immobilisation substrate for the voltammetric analysis of electroactive microparticles: the case of some artistic colouring agents. Anal. Bioanal. Chem. 405 (2013) 3603-3610.

[24] T. Grygar, J. Hradilova, D. Hradil, P. Bezdicka, S. Bakardjieva, Electrochemical analysis of natural solid organic dyes and pigments. Anal. Bioanal. Chem. 375 (2003) $1154-1160$ 
[25] A. Doménech-Carbó, M.T. Doménech-Carbó, M.C. Saurí-Peris, J.V. GimenoAdelantado, F. Bosch-Reig, Electrochemical identification of anthraquinone-based dyes in solid microsamples by square wave voltammetry using graphite/polyester composite electrodes. Anal. Bioanal. Chem. 375 (2003) 1169-1175.

[26] A. Doménech-Carbó, M.T. Doménech-Carbó, M.C. Saurí_Peris, Electrochemical identification of flavonoid dyes in work of art samples by abrasive voltammetry at paraffin-impregnated graphite electrodes. Talanta 66 (2005) 769-782.

[27] A. Doménech-Carbó, M.T. Doménech-Carbó, M.L. Vázquez de Agredos-Pascual, Chemometric Study of Maya Blue from the Voltammetry of Microparticles Approach. Anal. Chem. 79 (2007) 2812-2821.

[28] A. Doménech-Carbó, M.T. Doménech-Carbó, H.G.M. Edwards, Identification of Earth Pigments in Highly Damaged Frescoes by Applying Multivariate Chemometric methods to Solid State Voltammetry. Electroanalysis 19 (2007) 1890-1900.

[29] A. Doménech-Carbó, M.T. Doménech-Carbó, H.G.M. Edwards, Application of Tafel analysis for quantitation in solid state voltammetry. Application to the analysis of cobalt and copper pigments in severely damaged frescoes. Anal. Chem. 80 (2008) 2704-2716.

[30] A. Doménech-Carbó, M.T. Doménech-Carbó, F. López, F.M. Valle-Algarra, L. Osete-Cortina, E. Arcos-Von Hartmann, Electrochemical characterization of Egyptian blue pigment in wall paintings using the voltammetry of microparticles methodology. Electroanalysis 25 (2013) 2621-2630.

[31] A. Doménech-Carbó, M.T. Doménech-Carbó, X. Mas-Barberá, Identification of lead pigments in nanosamples from ancient paintings and polychromed sculptures using voltammetry of nanoparticles/atomic force microscopy. Talanta 71 (2007) 1569-1579.

[32] A. Doménech-Carbó, M.T. Doménech-Carbó, F.M. Valle-Algarra, J.V. GimenoAdelantado, L. Osete-Cortina, F. Bosch-Reig, On-line database of voltammetric data of immobilized particles for identifying pigments and minerals in archaeometry, conservation and restoration (ELCHER database). Anal. Chim. Acta 927 (2016) 1-12.

[33] F. Benito-Doménech, Los Ribalta y la pintura valenciana de su tiempo. Diputación Provincial de Valencia, Valencia, 1987.

[34] D.M. Kowal, Ribalta y los ribaltescos. La evolución del estilo barroco en Valencia. Diputación Provincial de Valencia, Valencia, 1985, p. 114.

[35] N. Zakharchuk, S. Meyer, B. Lange, F. Scholz, A Comparative Study of Lead Oxide Modified Graphite Paste Electrodes and Solid Graphite Electrodes with Mechanically Immobilized Lead Oxides. Croat. Chem. Acta 73 (2000) 667-704.

[36] B. Meyer, B. Ziemer, F. Scholz, In Situ X-Ray Diffraction Study of the Electrochemical reduction of Tetragonal Lead oxide and Orthorhombic $\mathrm{Pb}(\mathrm{OH}) \mathrm{Cl}$ Mechanically Immobilized on a Graphite Electrode. J. Electroanal. Chem. 392 (1995) 79-83. 
[37] U. Hasse, F. Scholz, In situ atomic force microscopy of the reduction of lead oxide nanocrystals immobilised on an electrode surface. Electrochem. Commun. 3 (2001) 429-434.

[38] M. Lovric, F. Scholz, A model for the propagation of a redox reaction through microcrystals. J. Solid State Electrochem. 1 (1997) 108-113.

[39] M. Lovric, M. Hermes, F. Scholz, The effect of the electrolyte concentration in the solution on the voltammetric response of insertion electrodes. J. Solid State Electrochem. 2 (1998) 401-404.

[40] K.B. Oldham, Voltammetry at a three-phase junction. J. Solid State Electrochem. 2 (1998) 367-377.

[41] M. Lovric, F. Scholz, A model for the coupled transport of ions and electrons in redox conductive microcrystals. J. Solid State Electrochem. 3 (1999) 172-175.

[42] U. Schröder, K.B. Oldham, J.C. Myland, P.J. Mahon, F. Scholz, Modelling of solid state voltammetry of immobilized microcrystals assuming an initiation of the electrochemical reaction at a three-phase junction. J. Solid State Electrochem. 4 (2000) 314-324.

[43] L. Baij, J.J. Hermans, K. Keune, P. Iedema, Time-Dependent ATR-FTIR Spectroscopic Studies on Fatty Acid Diffusion and the Formation of Metal Soaps in Oil Paint Model Systems. Angew. Chem. Int. Ed. (2018) DOI: 10.1002/anie.201712751.

[44] J.J. Hermans, K. Keune, A. van Loon, R.W. Corkery, P.D. Iedema, Ionomer-like structure in mature oil paint binding media. RSC Adv. 6 (2016) 93363-93369.

[45] L. De Viguerie, M. Jaber, H. Pasco, J. Lalevée, F. Morlet-Savay, G. Ducouret, B. Rigaud, T. Pouget, C. Sanchez, P. Walter, A $19^{\text {th }}$ Century "Ideal" Oil Paint Medium: A Complex Hybrid Organic-Inorganic Gel. Angew. Chem. Int. Ed. 56 (2017) 1619-1623.

[46] L. Robinet, M.C. Corbeil, The characterization of metal soaps. Stud. Conserv. 48 (2003) 23-40.

[47] R. Mazzeo, S. Prati, M. Quaranta, E. Joseph, E. Kendix, M. Galeotti, Attenuated total reflection micro FTIR characterisation of pigment-binder interaction in reconstructed paint films. Anal. Bioanal. Chem. 392 (2008) 65-76.

[48] D. Goltz, J. McClelland, A. Schellenberg, M. Attas, E. Cloutis, C. Collins, Spectroscopic Studies on the Darkening of Lead White. Appl. Spectroscop. 57 (2003) 1393-1398.

[49] A. Doménech-Carbó, Voltammetric methods applied to identification, speciation and quantification of analytes from works of art: an overview. J. Solid State Electrochem. 14 (2010) 363-379. 
[50] A.S. Ortiz-Miranda, A. Doménech-Carbó, M.T. Doménech-Carbó, L. OseteCortina, F. Bolívar-Galiano, I. Martín-Sánchez, M.M. López-Miras, Electrochemical characterization of biodeterioration of paint films containing cadmium yellow pigment. J. Solid State Electrochem. 20 (2016) 3287-3302.

[51] A.S. Ortiz-Miranda, A. Doménech-Carbó, M.T. Doménech-Carbó, L. OseteCortina, F. Bolívar-Galiano, I. Martín-Sánchez, Analyzing chemical changes in verdigris pictorial specimens upon bacteria and fungi biodeterioration using voltammetry of microparticles. Heritage Science 5 (2017) a.n. 8.

[52] Kh.Z. Brainina, M.B. Vidrevich, Stripping analysis of solids. J. Electroanal. Chem. 121 (1981) 1-28.

[53] T. Grygar, Phenomenological kinetics of irreversible electrochemical dissolution of metal-oxide microparticles. J. Solid State Electrochem. 2 (1998) 127-136.

[54] V. Mamleev, S. Boubigot, M.L. Bras, S. Duggesne, J. Sestak, Modelling of Nonisothermal kinetics in thermogravimetry. PhysChemChemPhys 2 (2000) 4708-4716.

[55] S. Balsubramanian, B. Lakshmanan, C.E. Hetzke, V.A. Sethuraman, J.W. Weidner, Quantifying oxidation rates of carbon monoxide on a Pt/C electrode. Electrochim. Acta 58 (2011) 723-728. 
Table 1. Detail of paintings in this study. ${ }^{\text {a }}$ Estimated from stylistic and historic data.

\begin{tabular}{|c|c|c|c|c|}
\hline Code & Oeuvre & Painter & Date $^{\text {a }}$ & Provenance \\
\hline $\begin{array}{l}\text { SJP01 to } \\
\text { SJP10 }\end{array}$ & $\begin{array}{l}\text { San Jerónimo } \\
\text { Penitente }\end{array}$ & $\begin{array}{l}\text { Nicolás } \\
\text { Borrás }\end{array}$ & $1575-1600$ & $\begin{array}{l}\text { Private coll. (Valencia, } \\
\text { Spain) }\end{array}$ \\
\hline $\begin{array}{l}\text { SJE01 to } \\
\text { SJE06 }\end{array}$ & $\begin{array}{l}\text { San Juan } \\
\text { Evangelista y el } \\
\text { filósofo Cratón }\end{array}$ & $\begin{array}{l}\text { Nicolás } \\
\text { Borrás }\end{array}$ & $1575-1600$ & $\begin{array}{l}\text { Private coll. (Valencia, } \\
\text { Spain) }\end{array}$ \\
\hline $\begin{array}{l}\text { SNJ1 to } \\
\text { SNJ12 }\end{array}$ & $\begin{array}{l}\text { Sueño del Niño } \\
\text { Jesús }\end{array}$ & $\begin{array}{l}\text { Vicente } \\
\text { Castelló }\end{array}$ & $1600-1630$ & $\begin{array}{l}\text { Asilo de Nuestra Señora de } \\
\text { los Desamparados, } \\
\text { Carcaixent (Spain) }\end{array}$ \\
\hline $\begin{array}{l}\text { IC01 to } \\
\text { IC04 }\end{array}$ & $\begin{array}{l}\text { Inmaculada } \\
\text { Concepción }\end{array}$ & $\begin{array}{l}\text { Jerónimo } \\
\text { Jacinto de } \\
\text { Espinosa }\end{array}$ & ca. 1660 & $\begin{array}{l}\text { Private coll. (Valencia, } \\
\text { Spain) }\end{array}$ \\
\hline $\begin{array}{l}\text { CV01 to } \\
\text { CV07 }\end{array}$ & $\begin{array}{l}\text { Coronación de la } \\
\text { Virgen }\end{array}$ & $\begin{array}{l}\text { Jerónimo } \\
\text { Jacinto de } \\
\text { Espinosa }\end{array}$ & $1660-1667$ & $\begin{array}{l}\text { Private coll. (Valencia, } \\
\text { Spain) }\end{array}$ \\
\hline $\begin{array}{l}\text { NV01 to } \\
\text { NV06 }\end{array}$ & $\begin{array}{l}\text { Nacimiento de la } \\
\text { Virgen }\end{array}$ & $\begin{array}{l}\text { Jerónimo } \\
\text { Jacinto de } \\
\text { Espinosa } \\
\end{array}$ & ca. 1650 & $\begin{array}{l}\text { Iglesia de San Nicolás de } \\
\text { Bari (Valencia, Spain) }\end{array}$ \\
\hline $\begin{array}{l}\text { NSJ1 to } \\
\text { NSJ9 }\end{array}$ & $\begin{array}{l}\text { Nacimiento de San } \\
\text { Juan }\end{array}$ & $\begin{array}{l}\text { Jerónimo } \\
\text { Jacinto de } \\
\text { Espinosa }\end{array}$ & ca. 1650 & $\begin{array}{l}\text { Iglesia de San Nicolás de } \\
\text { Bari (Valencia, Spain) }\end{array}$ \\
\hline $\begin{array}{l}\text { SCR1 to } \\
\text { SCR4 }\end{array}$ & $\begin{array}{l}\text { San Cristóbal de } \\
\text { Licia }\end{array}$ & $\begin{array}{l}\text { Vicente } \\
\text { Requena }\end{array}$ & $1590-1605$ & $\begin{array}{l}\text { Private coll. (Valencia, } \\
\text { Spain) }\end{array}$ \\
\hline $\begin{array}{l}\text { EH01 to } \\
\text { EH08 }\end{array}$ & Ecce Homo & $\begin{array}{l}\text { Francisco } \\
\text { Ribalta }\end{array}$ & $1600-1610$ & $\begin{array}{l}\text { Private coll. (Valencia, } \\
\text { Spain) }\end{array}$ \\
\hline $\begin{array}{l}\text { CSJ1 to } \\
\text { CSJ4 }\end{array}$ & $\begin{array}{l}\text { Cabeza de San } \\
\text { Jaime }\end{array}$ & $\begin{array}{l}\text { Francisco } \\
\text { Ribalta }\end{array}$ & ca. 1603 & $\begin{array}{l}\text { Private coll. (Valencia, } \\
\text { Spain) }\end{array}$ \\
\hline $\begin{array}{l}\text { SP01 to } \\
\text { SP05 }\end{array}$ & $\begin{array}{l}\text { San Pedro } \\
\text { Llorando }\end{array}$ & $\begin{array}{l}\text { Juan } \\
\text { Ribalta }\end{array}$ & 1628 & $\begin{array}{l}\text { Monasterio de la } \\
\text { Inmaculada Concepción, } \\
\text { Torrent (Spain) }\end{array}$ \\
\hline $\begin{array}{l}\text { IN01 to } \\
\text { IN08 }\end{array}$ & $\begin{array}{l}\text { Inmaculada } \\
\text { Concepción }\end{array}$ & $\begin{array}{l}\text { Juan } \\
\text { Sariñena }\end{array}$ & $1580-1590$ & $\begin{array}{l}\text { Private coll. (Valencia, } \\
\text { Spain) }\end{array}$ \\
\hline
\end{tabular}


Table 2. Values of the coefficients $\alpha$ and $\left(g_{\mathrm{III}} / g_{\mathrm{I}}\right) G$ calculated from experimental data in Figure 8 for yellow/green areas of the studied paintings. Statistical parameters (correlation coefficient $r$, F-statistic $F$, and sum of squared residuals, $s$ ) calculated for the fitting of experimental data to the logarithmic form of Eq. (9).

\begin{tabular}{|l|l|l|l|l|l|}
\hline Painter/ & $\left(g_{\mathrm{III}} / g_{\mathrm{I}}\right) \boldsymbol{G}$ & $\alpha$ & $\boldsymbol{F}$ & $\boldsymbol{s}$ \\
\hline Norkshop & & & & & \\
\hline Vicolás Borrás & $(5.0 \pm 0.8) \times 10^{-3}$ & $1.43 \pm 0.09$ & 0.96 & 36.1 & 0.722 \\
\hline $\begin{array}{l}\text { Jerónimo Jacinto } \\
\text { de Espinosa }\end{array}$ & $(1.5 \pm 0.8) \times 10^{2}$ & $0.70 \pm 0.05$ & 0.96 & 34.8 & 0.865 \\
\hline $\begin{array}{l}\text { Vicente Requena } \\
\text { Francisco }\end{array}$ & $(5.0 \pm 0.5) \times 10^{-2}$ & $1.20 \pm 0.04$ & 0.994 & 169 & 0.138 \\
\hline Ribalta & $(2.4 \pm 1.2) \times 10^{3}$ & $0.48 \pm 0.03$ & 0.98 & 56.6 & 0.255 \\
\hline Juan Ribalta & $(3.2 \pm 1.4) \times 10^{3}$ & $0.43 \pm 0.02$ & 0.96 & 11.8 & 0.256 \\
\hline Juan Sariñena & $(1.8 \pm 0.5) \times 10^{-3}$ & $1.45 \pm 0.02$ & 0.997 & 491 & 0.388 \\
\hline
\end{tabular}




\section{Figures}

Figure 1. Photographic image of the painting San Cristóbal de Licia by Vicente Requena (a) accompanied by a microphotograph of the cross-section of the SCR2 sample containing of white, yellow and green pigments in the paint layer (the outer (b) and the X-ray spectrum (c) of a yellow grain, showing the characteristic features of lead-tin yellow. The pictorial layer was deposited over preparative layers of gypsum (g) and red earths accompanied by minium and lead white (r).

Figure 2. SWVs of samples a,b) SNJ11 and c,d) SJP3 attached to graphite electrodes in contact with air-saturated $0.25 \mathrm{M} \mathrm{HAc} / \mathrm{NaAc}$ aqueous solution at $\mathrm{pH} 4.75$. Potential scan initiated at $1.25 \mathrm{~V}$ in the negative direction; potential step increment $4 \mathrm{mV}$; square wave amplitude $25 \mathrm{mV}$; frequency $5 \mathrm{~Hz}$. The arrows indicate the direction of the potential scanning.

Figure 3. Detail of SWVs, after semi-derivative convolution, of samples from green areas of: a) IN3, b) IN8, c) NSJ6, d) SNJ9, e) EH1 and f) SP3, attached to graphite bars in contact with air-saturated 0.25 M HAc/NaAc aqueous solution at $\mathrm{pH} 4.75$. Staring potential: $1.25 \mathrm{~V}$; potential step increment $4 \mathrm{mV}$; square wave amplitude $25 \mathrm{mV}$; frequency $5 \mathrm{~Hz}$. The arrows indicate the direction of the potential scanning.

Figure 4. Backscattered electron image of a cross-section of a sample from a greenish area in the Ecce Homo painting by Francisco Ribalta showing grains of lead white surrounded by a dark grey envelope of lead soaps (dotted line).

Figure 5. Simplified scheme for interpreting the lead-based electrochemistry of paint samples in this study.

Figure 6. a) Representation of the peak current for the reduction of lead compounds between -0.2 and $-0.8 \mathrm{~V}(\mathrm{C}(\mathrm{Pb}))$ and the current for the OER at the extreme of positive potentials in voltammograms such as in Figures 2a,c, and the peak current for the stripping of lead (process $\mathrm{A}(\mathrm{Pb})$ ) in voltammograms such as in Figure $2 \mathrm{~b}, \mathrm{~d}$. b-d) Representation of $i($ II) vs. $i$ (III) for yellow and green samples in this study from 
deconvoluted voltammograms such as in Figure 3 (criteria for measuring currents depicted in Figure S.4 of Supplementary Information). b) Data for all paint samples; c) data points for Nicolás Borrás, Juan Sariñena and Vicente Requena; d) data points for Jerónimo Jacinto de Espinosa, Francisco Ribalta and Juan Ribalta (d). Continuous lines correspond to the fit of experimental data to potential curves.

Figure 7. a) Schematics for the reduction of lead pigment grains surrounded by a thin layer of lead soaps in a paint specimen adhered to a graphite electrode in contact with an aqueous electrolyte. b,c) Theoretical curves for different $\alpha$ values in Eq. (9) taking; b) $g_{\mathrm{III}} / g_{\mathrm{I}}=0.10$ and $G=0.10 ;$ c) $g_{\mathrm{III}} / g_{\mathrm{I}}=0.10$ and $G=100$.

Figure 8. Plots of $i(\mathrm{II}) / i(\mathrm{III})$ vs. $i$ (III) for samples from yellow and green (empty figures) and white (solid figures) areas of the studied paintings (see Table 1) of: a) Jerónimo Jacinto de Espinosa (squares) and Vicente Requena (triangles), b) Juan Borrás, c) Juan Sariñena, d) Francisco Ribalta (squares), Juan Ribalta (triangles) and Vicent Castelló (rhombs). Voltammetric data in conditions such as in Figure 3; currents measured using the criteria depicted in Figure S.4 (Supplementary information). Correlation coefficients determined upon fitting data to a potential function.

Figure 9. Two-dimensional diagram of $\alpha$ vs. $\log G$ determined fitting experimental data to Eq. (9) for painters/workshops in this study. Rectangles of error taken from Table 2. The arrows mark the historically documented direct relationships between painters $[33,34]$. 
Figure 1.

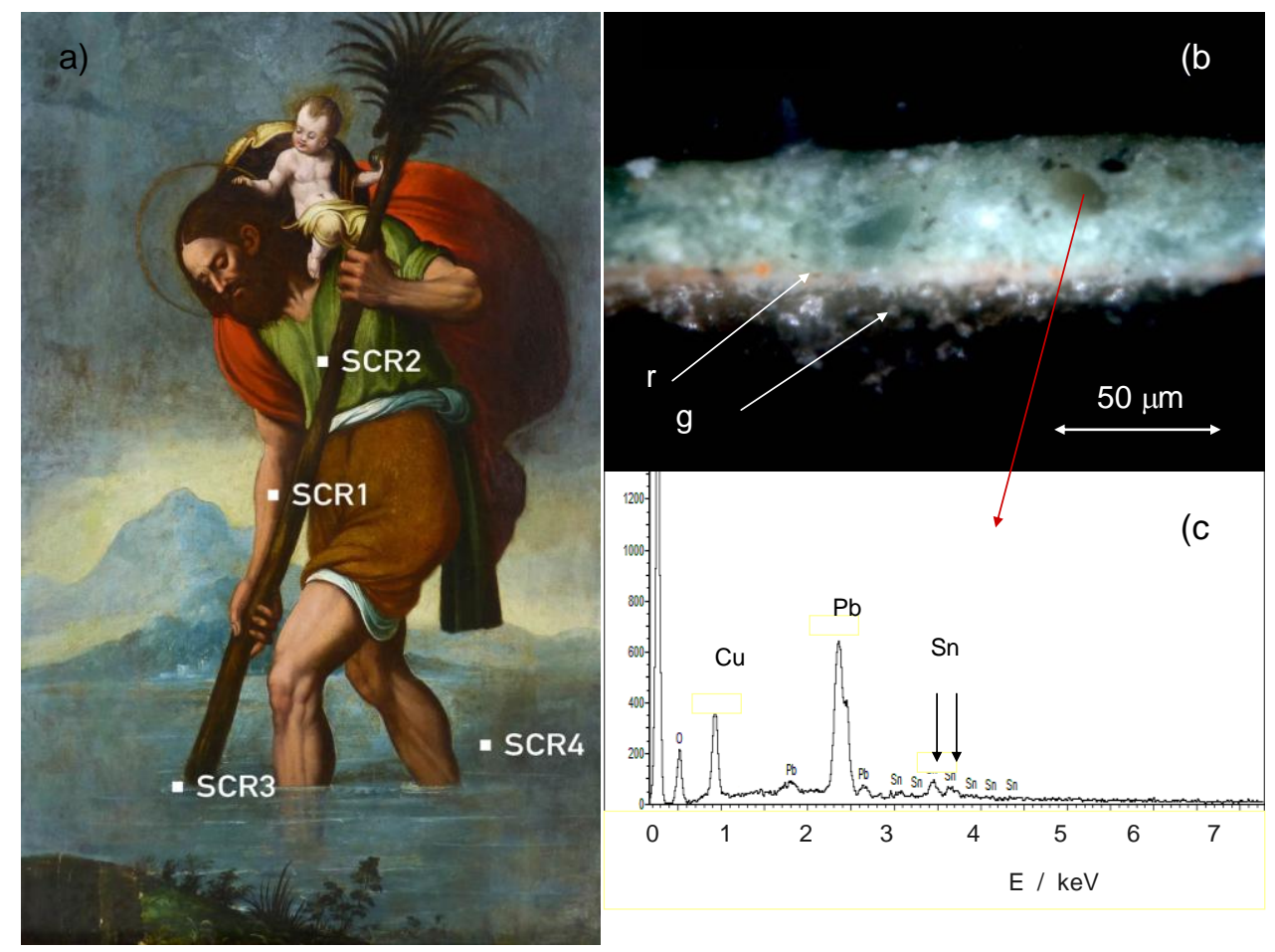


Figure 2.

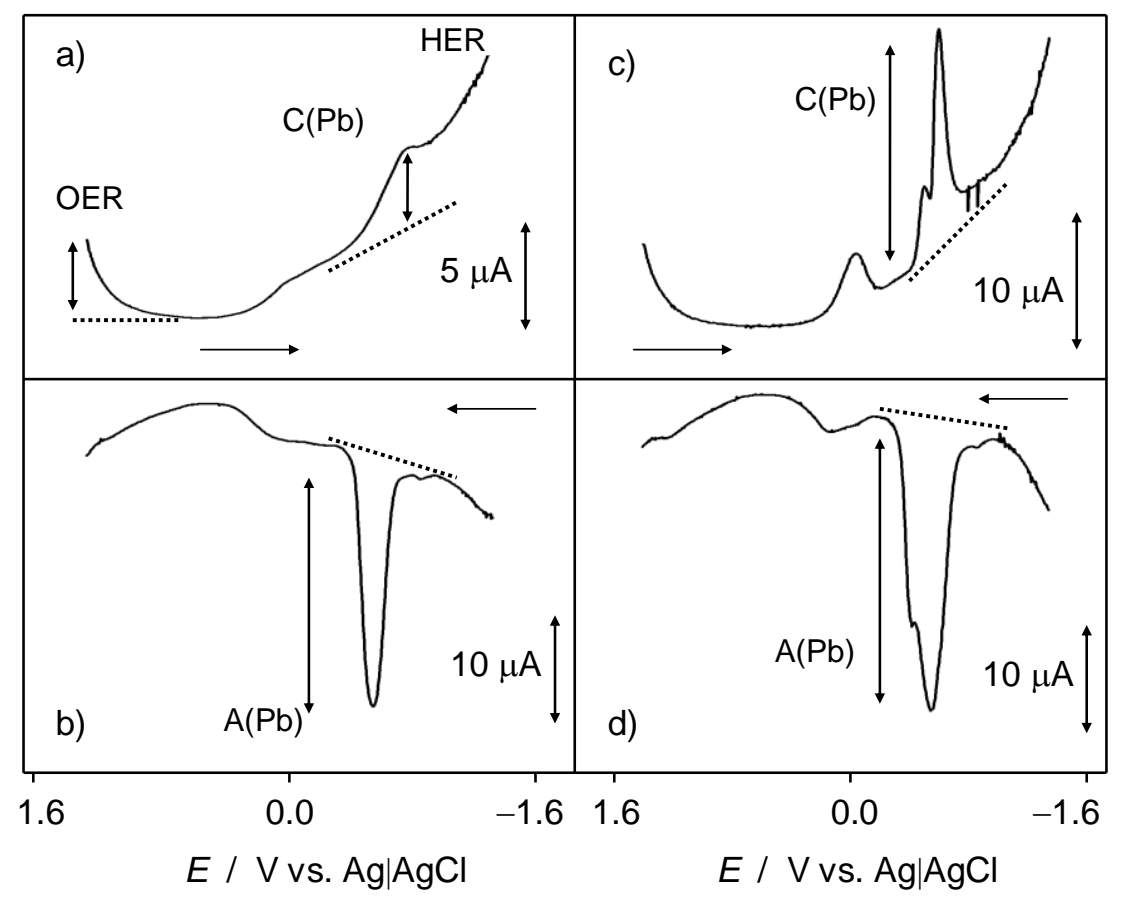


Figure 3.
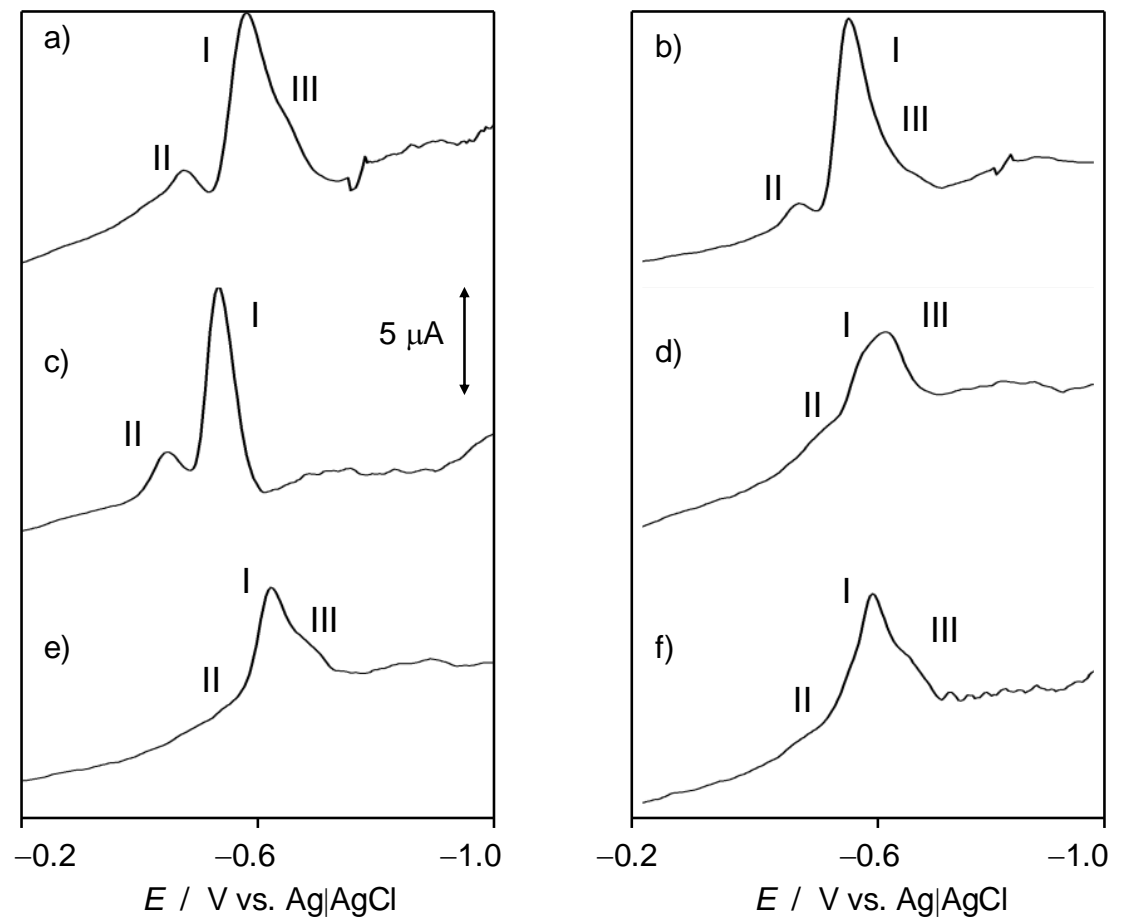
Figure 4.

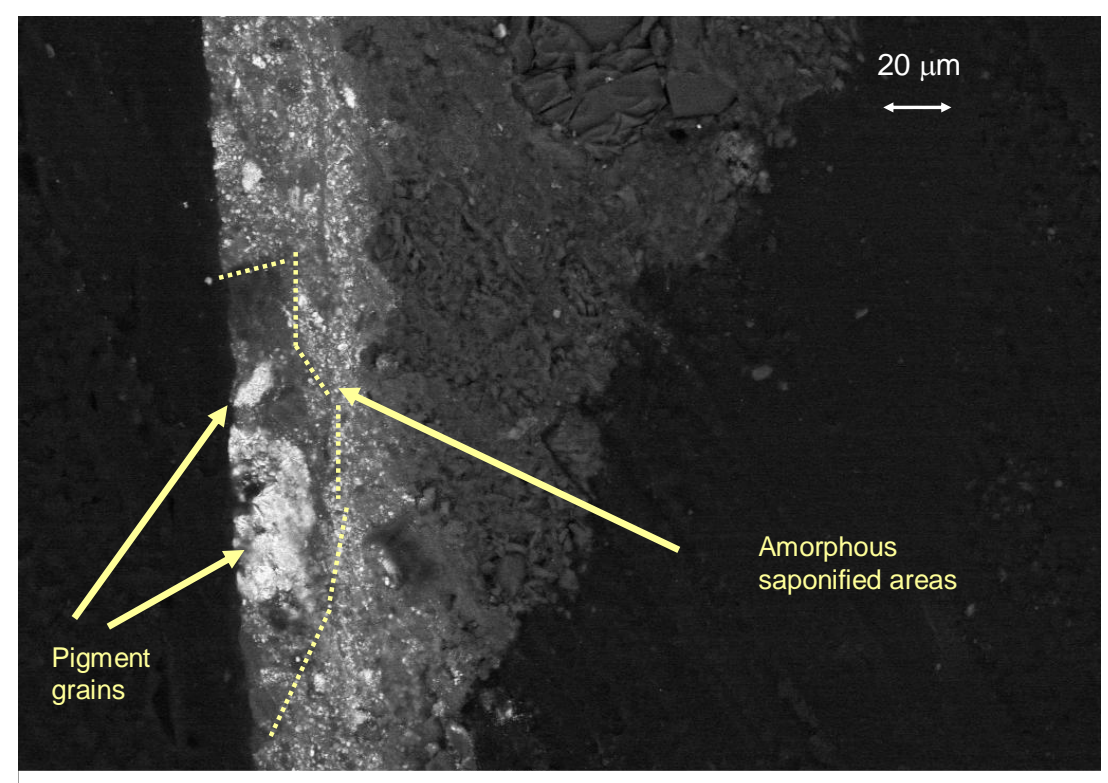


Figure 5.

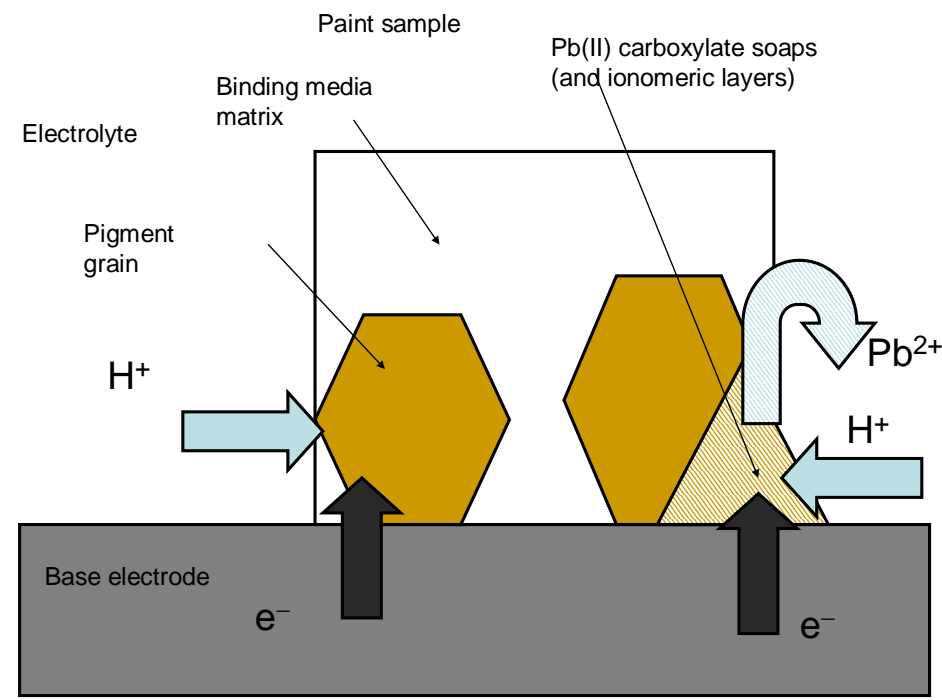


Figure 6.
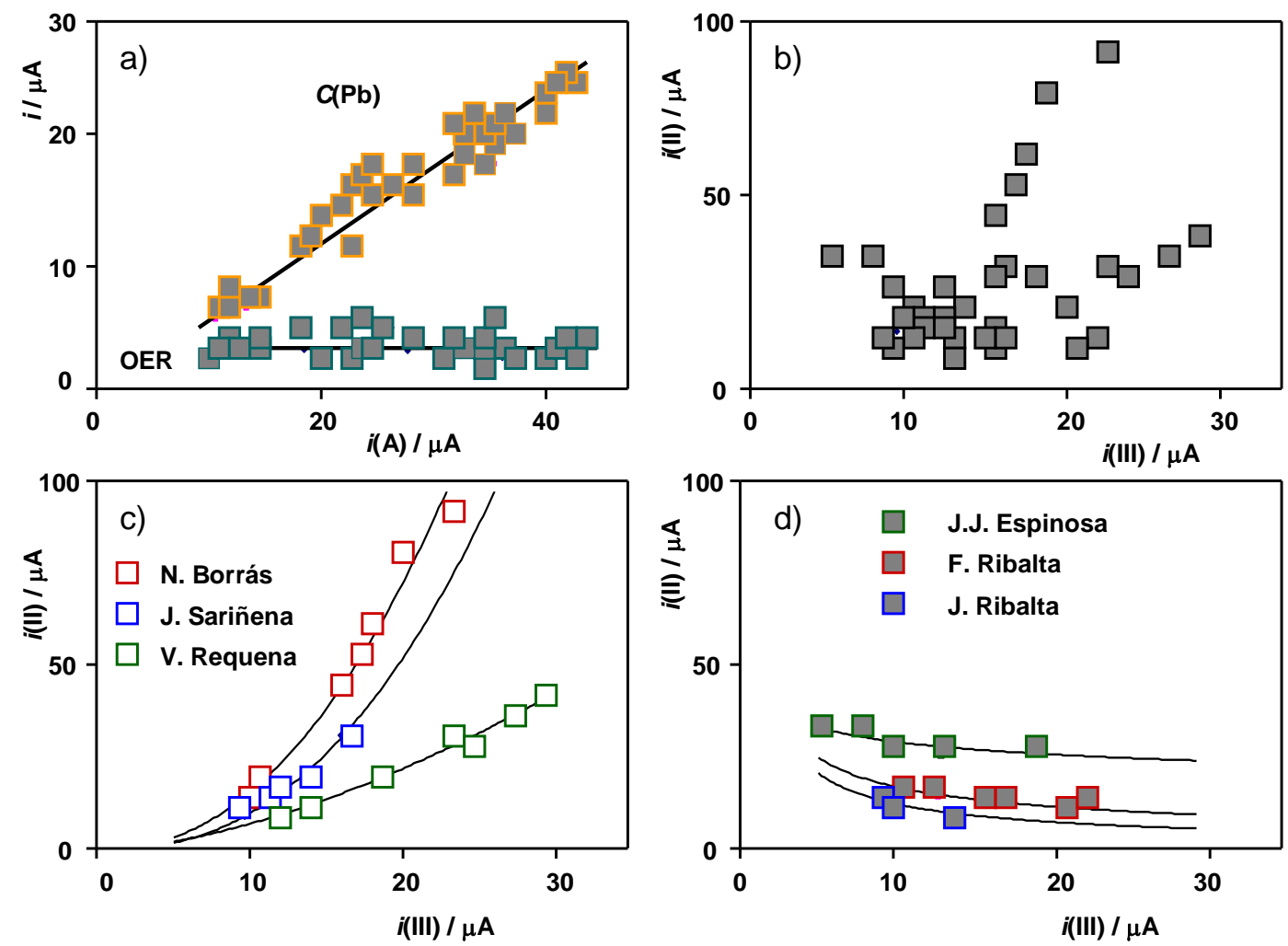
Figure 7.
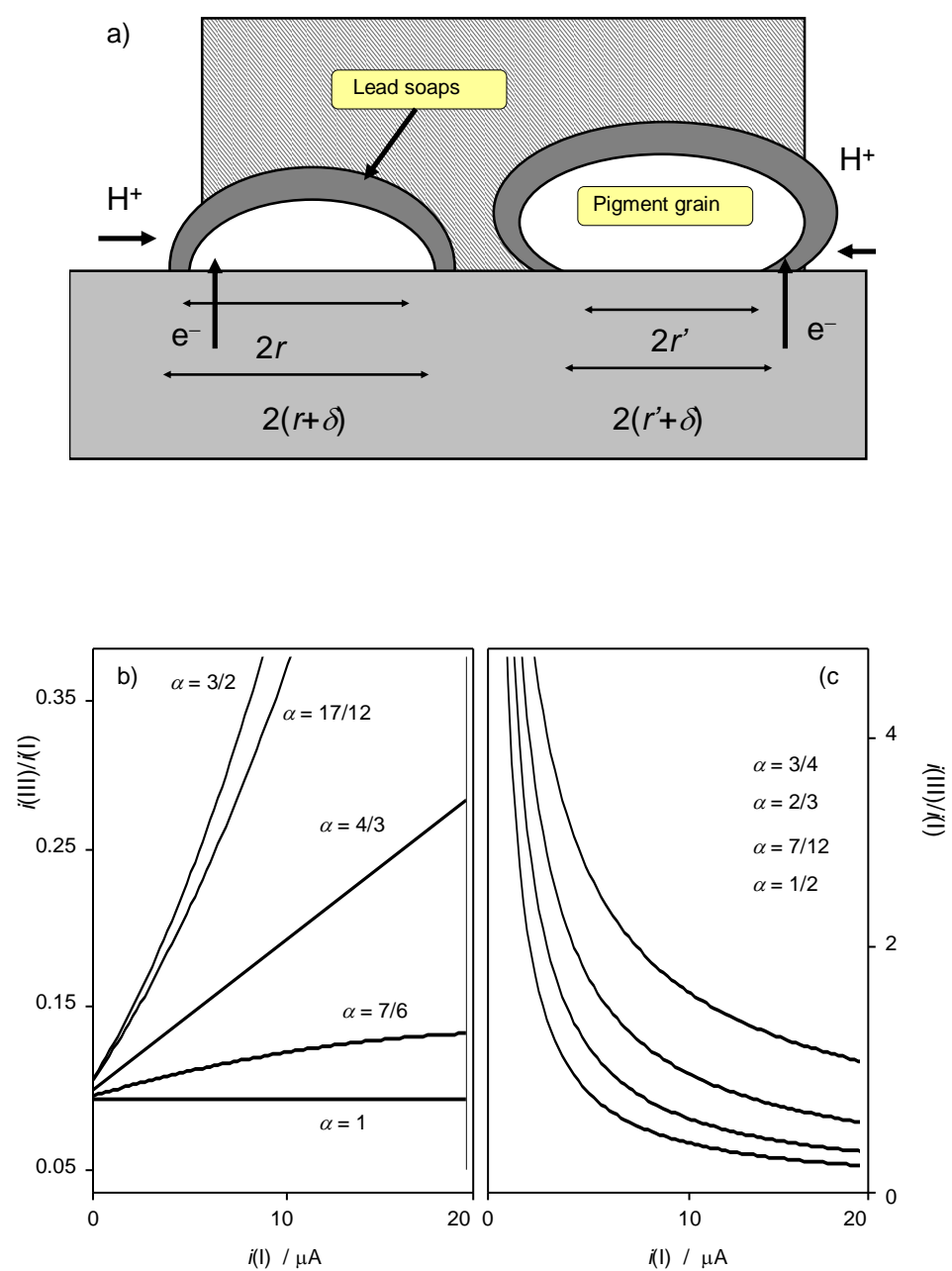
Figure 8.
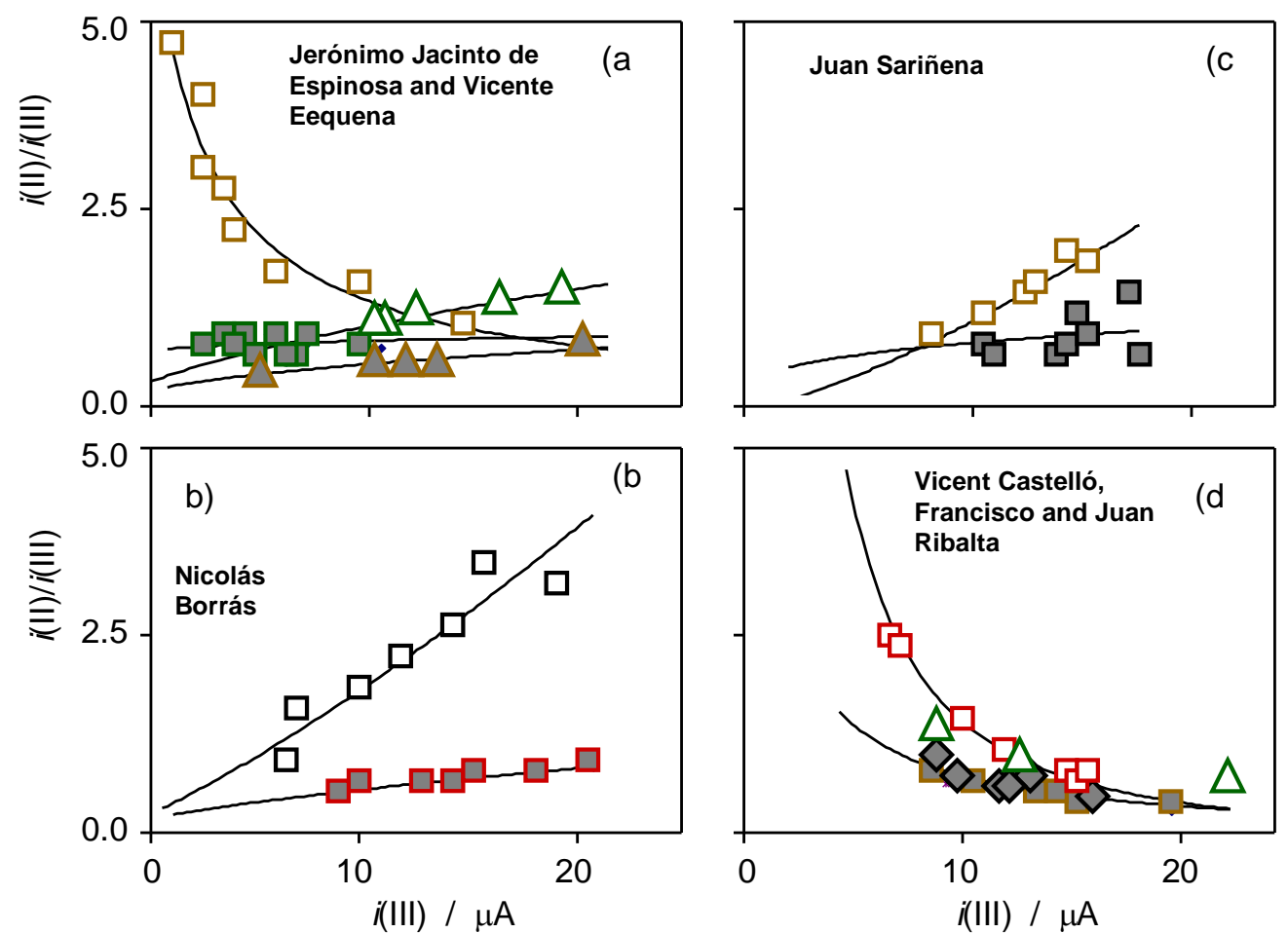
Figure 9.

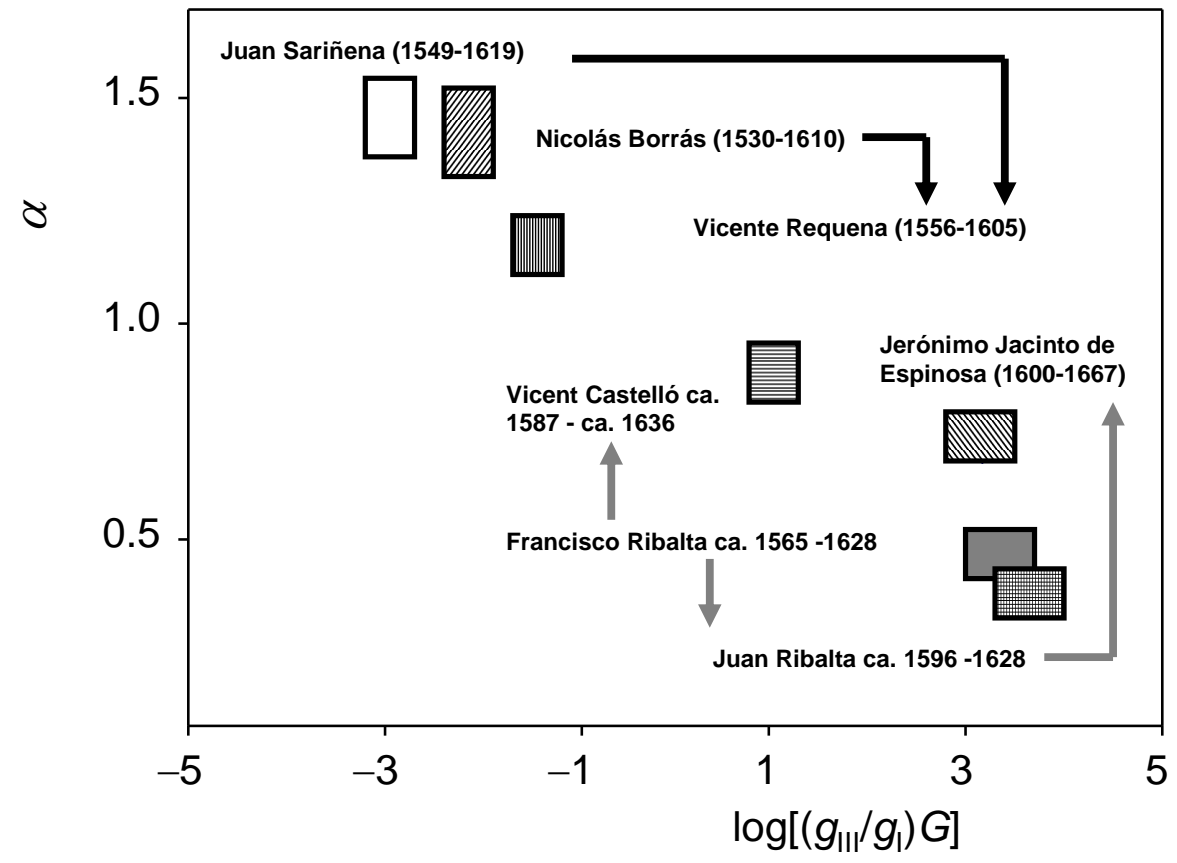

